Gut, 1972, 13, 64-65

\title{
Anhydrous cholesterol: a new crystalline form in gallstones
}

\author{
D. JUNE SUTOR AND P. J. GASTON \\ From the Department of Chemistry, University College, London
}

SUMMARY A new crystalline form of anhydrous cholesterol called cholesterol II has been found in gallstones. This material can change within a few weeks into the usual form of anhydrous cholesterol but pure synthetic cholesterol II is stable.

In an $x$-ray study of 331 gallstones from eight countries, different forms of cholesterol accounted for $71 \%$ of the total crystalline material (Sutor and Wooley, 1969, 1971); $52.3 \%$ was anhydrous cholesterol, $16 \%$ cholesterol monohydrate, and $2.7 \%$ a compound, subsequently called cholesterol II, but then of unknown composition. Cholesterol II was usually found admixed with anhydrous cholesterol, but sometimes it comprised the whole stone; in a few cases it occurred with cholesterol monohydrate, and in one instance it was associated with the three forms of calcium carbonate-calcite, aragonite, and vaterite. Its $x$-ray diffraction pattern, used throughout for identification purposes, only differed from that of anhydrous cholesterol in the interplanar spacing and intensity of some of the strongest lines. This strongly suggested that cholesterol II might be another form of anhydrous cholesterol, but it could also be a closely similar compound or some intermediate formed in the dehydration of cholesterol monohydrate to the anhydrous compound. This reaction, and the reverse transformation which occurs in the presence of water, sometimes takes place in a few days. For this reason and because cholesterol deposits freshly removed from the body were always the monohydrate, it has been suggested that the monohydrate is the form laid down in vivo (Bogren and Larsson, 1963).

Cholesterol II was obtained by recrystallizing some impure, commercial anhydrous cholesterol (analysis figures compared with those for the pure material in brackets are $\mathrm{C}=79.83 \%(83.85), \mathrm{H}=$ $11 \cdot 12 \%(11.98)$ ) from benzene or chloroform. Another brand of reagent grade material consisted of a mixture of anhydrous cholesterol and cholesterol II. The composition was not changed by crystallization from chloroform, and analysis figures, before

Received for publication 15 November 1971. and after recrystallization, agreed within experimental error with those for the anhydrous compound. On the other hand, pure commercial anhydrous cholesterol (verified by analysis and $x$-ray diffraction) from the same two companies was not changed by crystallization from either of these solvents. Cholesterol II, isolated by chromatography from the impure commercial material, repeatedly recrystallized from choloroform, and dried over phosphorus pentoxide, had a melting point of $138-139^{\circ} \mathrm{C}$ and gave analysis figures $(\mathrm{C}=82.87 \%$, $\mathrm{H}=11.69 \%$ ) not compatible with any simple empirical formula. This material also gave a red colouration with 2, 4 dinitrophenylhydrazine indicative of the presence of a carbonyl group. Since such a group in the cholesterol skeleton is not in accordance with the analysis figures and $x$-ray data, it must be present in an impurity possibly necessary for the formation of cholesterol II. When pure commercial cholesterols were recrystallized from chloroform in the presence of a trace of ketone, cholest-4-en-3-one, cholesterol II was obtained.

Thin-layer chromatography using as solvent ethyl acetate and petroleum ether in varying proportions confirmed that the pure commercial cholesterol consisted of a single compound, but showed that both the impure commercial sample and cholesterol II prepared from it contained predominantly a compound with the same $R_{F}$ factor as the pure material and traces of at least five other compounds. Cholesterol II from gallstones gave the same spot as pure anhydrous cholesterol and contained no detectable impurity using these techniques. All available evidence therefore suggests that pure cholesterol II is another crystalline form of anhydrous cholesterol.

Although cholesterol monohydrate dehydrates to the more common anhydrous compound, some monohydrate prepared by recrystallization of the impure commercial cholesterol from alcohol, partly 
changed over a period of a year, into cholesterol II. This material was stable at room temperature for several months as was the impure cholesterol II prepared by recrystallization of the impure commercial sample from chloroform or benzene. In gallstones, however, cholesterol II can change into anhydrous cholesterol in just a few weeks. Conversion of cholesterol II into the monohydrate by leaving it in contact with water for several months, using synthetic material and that from gallstones, has not been possible. One cannot speculate as to whether cholesterol II is laid down in vivo, although it has been found in gallstones examined within three days after their removal at operation, since even traces of impurities might accelerate and favour the decomposition of the monohydrate into this compound.

One of us (D.J.S.) thanks the Nuffield Foundation for financial support.

References

Bogren, H., and Larsson, D. (1963). An X-ray diffraction study of crystalline cholesterol in some pathological deposits in man. Biochim. biophys. Acta (Amst.), 75, 65-69.

Sutor, D. J., and Wooley, S. E. (1969). $X$-ray diffraction studies of the composition of gallstones from English and Australian patients. Gut, 10, 681-683.

Sutor, D. J., and Wooley, S. E. (1971). A statistical survey of the composition of gallstones in eight countries. Gut, 12, 55-64.

\section{The December 1971 Issue}

\section{THE DECEMBER 1971 ISSUE CONTAINS THE FOLLOWING PAPERS}

Serum gastrin in duodenal ulcer Part II Effect of insulin hypoglycaemia J. HANSKY, M. G. KORMAN, D. J. COWLEY, AND J. H. BARON

The influence of the individual surgeon and of the type of vagotomy upon the insulin test after vagotomy DAVID JOHNSTON AND J. C. GOLIGHER

Secretin and cholecystokinin/pancreozymin in combination in the inhibition of gastric acid secretion B. S. BEDI, H. T. DEbas, A. E. O. WASUNNA, B. F. BUXTON, AND I. E. GILLESPIE

The effect of fat on calcium absorption from a mixed meal in normal subjects, patients with malabsorptive disease, and patients with a partial gastrectomy J. E. AGNEW AND C. D. HOLDSWORTH

${ }^{47}$ Calcium absorption in parenchymatous and biliary liver disease MICHAEL J. WHELTON, A. K. KEHAYOGLOU, J. E. AGNEW, L. A. TURNBERG, AND SHEILA SHERLOCK

Changes of the smooth endoplasmic reticulum induced by rifampicin in human and guinea-pig hepatocytes A. M. JEZEQUEL, F. ORLANDI, AND L. T. TENCONI

Quantitation of intraepithelial lymphocytes in human jejunum ANNE FERGUSON AND D. MURRAY
The surgical significance of methaemalbuminaemia CAMERON BATTERSBY AND MARJORIE K. GREEN

Glucose absorption kinetics in Zambian African patients with and without systemic bacterial infections G. C. COOK

Mechanism of fat malabsorption in rats infected with Nippostrongylus brasiliensis N. D. GALLAGHER, M. R. PLAYOUST, AND L. E. A. SYMONS

Relationship of hepatic iron concentration to histochemical grading and to total chelatable body iron in conditions associated with iron overload R. J. WALKER, J. P. G. MILLER, I. W. DYMOCK, K. B. SHILKIN, AND ROGER WILLIAMS

A search for nitrosamines in East African spirit samples from areas of varying oesophageal cancer frequency C. H. COllis, PAUla J. COOK, J. K. FOREMAN, AND J. F. PALFRAMAN

Mycobacteriophage in Crohn's disease KEVIN PARENT AND I. DODD WILSON

Progress report Diarrhoea: Mechanisms and treatment T. S. LOW-BEER AND A. E. READ

Notes and activities

Index to Volume 12

Contents of Volume 12

Copies are still available and may be obtained from the PUBLISHING MANAGER, BRITISH MEDICAL ASSOCIATION, TAVISTOCK SQUARE, LONDON, WC1 H 9JR, price 87 $\frac{1}{2} \mathrm{p}$ 